\title{
Broadleaves in the Interior of British Columbia: Their extent, use, management and prospects for investment in genetic conservation and improvement
}

\author{
by Alan Vyse ${ }^{1}$ and Suzanne W. Simard²
}

\begin{abstract}
The principal broadleaves in Interior British Columbia (trembling aspen, paper birch, balsam poplar and black cottonwood) are well distributed across all of the major Interior ecological zones but their occurrence is greatest in the northern areas. Their utilization has gradually increased over the last 20 years, especially in the north. Economic values are low compared to conifer species but shortage of conifer timber as a result of the mountain pine beetle epidemic could drive demand for broadleaves higher. The ecological and non-timber values of broadleaves are very high; however, management practices still favour conifer species. Retention of broadleaves in harvesting and reforestation programs is widely implemented, but at a very low intensity and with little attention to broadleaf silvics. Future management of broadleaves is likely to be based largely on natural regeneration of broadleaves and not nursery production. Investments in genetic research should focus on genecology and gene conservation, as well as facilitated migration studies and investigation of pest resistance.
\end{abstract}

Key words: broadleaves, trembling aspen, paper birch, black cottonwood, balsam poplar, management, genetic conservation, genetic improvement

\section{RÉSUMÉ}

Les principaux feuillus retrouvés dans la région intérieure de la Colombie-Britannique (le peuplier faux-tremble, le bouleau blanc, le peuplier baumier et le peuplier baumier de l'Ouest) ont une distribution uniforme dans toutes les zones écologiques les plus importantes de la région intérieure, mais leur présence est plus dominante dans le nord de la province. Leur utilisation sest accrue de façon progressive au cours des 20 dernières années, surtout dans le nord. La valeur économique de ces bois est faible en comparaison avec les espèces résineuses, mais la pénurie de bois d’œuvre de résineux découlant de lépidémie du dendroctone du pin ponderosa pourrait faire progresser la demande de bois de feuillus. La valeur écologique et la valeur des produits autres que ceux liés au bois d’ouvre de feuillus sont très élevées; cependant, les pratiques d’aménagement continuent de favoriser les espèces résineuses. La rétention des feuillus lors de la coupe et dans les programmes de reboisement est implantée de façon générale, mais à un faible niveau et avec peu d’attention à la sylviculture des feuillus. Laménagement futur des feuillus reposera vraisemblablement sur la régénération naturelle des feuillus et non sur la production de semis en pépinière. Les investissements en matière de recherche génétique devraient être concentrés sur la génécologie et la conservation des caractéristiques génétiques, ainsi sur les études de migration et la recherche sur la résistance aux ravageurs.

Mots clés : feuillus, peuplier faux-tremble, bouleau blanc, peuplier baumier de l'Ouest, peuplier baumier, aménagement, conservation des caractéristiques génétiques, amélioration génétique

\footnotetext{
${ }^{1}$ Emeritus Scientist, B.C. Forest Service and Adjunct Professor, Department of Natural Resource Sciences, Thompson Rivers University, 2646 Valleyview Drive, Kamloops, British Columbia V2C 4E5. E-mail: vyse@telus.net

${ }^{2}$ Professor, Faculty of Foresty, University of British Columbia, 2424 Main Mall, Vancouver, British Columbia V6T 1 Z4.
} 


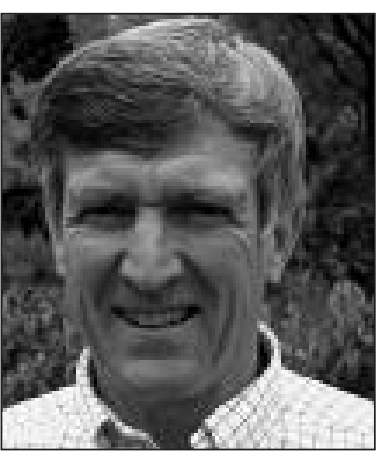

Alan Vyse

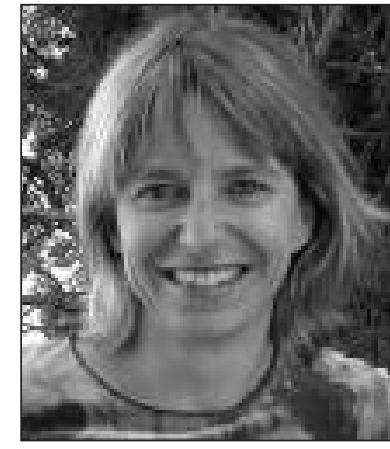

Suzanne W. Simard

\section{Introduction}

Broadleaved species ${ }^{3}$ play a major role in the landscape and culture of Canada. The maple leaf is our national symbol, maple syrup satisfies the sweet tooth of the country and the birchbark canoe was recently declared one of the 7 wonders of Canada. Management of these species, and others such as aspen, cherry, walnut, beech and oak, is commonplace. In British Columbia, however, there is a twist to the national picture. Although the Pacific dogwood is the Provincial floral symbol, western redcedar is the Provincial tree. Broadleaves have long played "second fiddle" to the abundant conifer resource and they are referred to as an "unsung" component of British Columbia's forests. Nevertheless, they occupy a significant proportion of the forested landscape. Pure stands of these species occupy $11 \%$ of the forested landscape and a further $24 \%$ of forest stands are mixtures of broadleaves and conifers (Comeau et al. 1996).

Until the 1990s, annual harvests of broadleaves were negligible, representing about $2 \%$ of the provincial harvest at most (Massie 1996), which is much smaller than their presence in the landscape might suggest. And to foresters of that time, broadleaves were considered a nuisance, subject to cutting or spraying because they threatened the dominance of market-favoured conifers. Since about 1990, the picture has begun to change. The ecological role of broadleaves in the many provincial forest types is acknowledged and their importance to First Nations cultures and rural communities is receiving more attention (Royal Roads 2006). The industrial harvest of broadleaves has increased, largely a result of advances in the manufacture of oriented strand board (OSB) products. Further recognition of the role of broadleaves is likely as a result of conifer harvest declines following the

\footnotetext{
${ }^{3}$ We prefer the terms "broadleaf and broadleaved" as descriptive singular and plural adjectives, and the term "broadleaves" as a collective noun. Although "hardwood" is the commonly used term in the United States and Eastern Canada for these species, we argue that this term is less useful in British Columbia. Of the species we have considered in this report, only paper birch fits the literal interpretation of a hardwood. However, it is no "harder" than several conifer or B.C. "softwood" species. Both aspen and cottonwood are relatively low in density and have low hardness. Cottonwood is especially low in density and it is a true "softwood." Not surprisingly, the terms "hardwood" and "softwood" are confusing to the public, and while they have the merit of having a long history in eastern North America, they do not fit well with modern ecologically based forestry. Wood is not the only, nor is it even the most important, forest value in the public eye.
}

mountain pine beetle epidemic in the province (BC MFR $2007 \mathrm{c}$ ) and trends toward managing stands for greater ecological resiliency and for mixed species (BC MFR 2006). If greater management activities do take place, the Forest Genetics Council of British Columbia is concerned that issues related to seed transfer, seed source, opportunities for genetically based growth and value gains, seed (or cuttings) production and management, and gene conservation will be raised without an adequate scientific basis for sound decisions (J. Woods, personal communication ${ }^{4}$ ).

In this paper, we assess priorities for expansion of broadleaf genetic testing and improved seed or vegetative production based on:

- review of the current and potential distribution of broadleaved species in the Interior of British Columbia

- current management of broadleaved and mixed broadleaved-conifer forest types

- potential for increasing the management and harvest of broadleaves

- status of biological and economic research on the key broadleaved species

- existing genetic improvement work

\section{Broadleaved Species in the Interior of British Columbia Principal species}

In the Interior of British Columbia there are 3 dominant broadleaved species of long term commercial interest: trembling aspen (Populus tremuloides Michx.); paper birch (Betula papyrifera Marsh. var. papyrifera); and poplar (Populus balsamifera L.), which has 2 sub-species, balsam poplar (ssp. balsamifera) and black cottonwood (ssp. trichocarpa [Torry and Gray] Brayshaw). The botanical terminology for paper birch and poplar has been subject to some debate, primarily because paper birch hybridises with other closely related native species, and the poplar subspecies inter-grade and are often difficult to tell apart. All 3 species occur throughout the Interior of British Columbia. Balsam poplar is restricted to the northeastern part of the province.

There are an additional 10 to 20 woody broadleaved species that can attain tree size in the Interior under favourable conditions. None of these have commercial importance for wood products at the present time, although they may be used for food and medicine and have high value for wildlife species. They include water, Alaska, scrub and swamp birch (Betula spp.), willow (Salix spp.), pin and choke cherry (Prunus spp.), Saskatoon (Amelancher alnifolia Nuttall), western and Sitka mountain ash (Sorbus spp.), green, Sitka and mountain alder (Alnus spp.), Douglas maple (Acer glabrum [Hooker] Dippel), cascara (Rhamnus purshiana DC), red-osier dogwood (Cornus stolonifera Michaux), hazel nut (Corylus cornuta Marshall), and black hawthorn (Crataegus douglasii Lindley).

\section{Existing and potential commercial ranges}

The principal broadleaved species grow to commercial size within the wetter forested Interior ecological zones (Interior Cedar Hemlock [ICH]; Sub-Boreal Spruce [SBS]; and Boreal White and Black Spruce [BWBS] ) and on sites with fresh to

\footnotetext{
${ }^{4}$ Jack Woods, Executive Director, Forest Genetics Council of
} British Columbia, Victoria, BC. 
wet soil moisture regime and medium to rich soil nutrient regime. They have no production potential in the high elevation zones (Engelmann Spruce-Subalpine Fir [ESSF]), the high latitude zone (Spruce-Willow-Birch [SWB]) and the driest forested zone (Ponderosa Pine $[\mathrm{PP}]$ ), and very limited potential in the dry Interior Douglas-fir (IDF) zone, and the cold and dry Sub-Boreal Pine and Spruce (SBPS) and Montane Spruce (MS) zones. Their general distribution appears to be limited by summer precipitation and various combinations of winter and summer temperatures.

Paper birch establishment is limited by frost (Carlson et al. 2000), which may explain its sharp upper elevation limit in the landscapes of the Interior, and by moisture deficits. Prolonged dry conditions, or winter thaw-freeze events (Bourque et al. 2005), may trigger "birch decline" that has been reported from the southern Interior in recent years $(M$. Cleary, pers. com. ${ }^{5}$ ). Bronze birch borer (Agrilus anxius Gory) has also been implicated in the decline (Peterson et al. 1997) along with 2 introduced birch leaf miners (Fenusa pusilla Lepeletier, Profenusa thomsoni Konow).

Cottonwood usually occupies valley bottoms and rarely reaches maturity on upland sites, probably as a result of moisture deficits. Aspen is less susceptible to lack of moisture than either birch or the poplars and also requires a lower level of nutrients. Aspen dieback has been reported throughout North America (Worrall et al. 2008), but no single cause has been identified. Multiple stressors, including forest tent caterpillar (Malacosoma disstria Hbn.), drought, and thaw-freeze, are thought responsible for dieback of aspen in Alberta, and there is concern that their severity will increase with climate change (Hogg et al. 2002).

Climate change is expected to have a major influence on the health of Canada's forested ecosystems in this century, with changes in forest disturbance regimes and the distribution of forest types projected. Hamann and Wang (2006) and McKenney et al. (2007) suggest that the currently wide distributions of trembling aspen, paper birch and poplar provide some degree of resilience to climate change. However, this conclusion does not take into account the possibility of changes in pest impacts or other damaging agents. For example, Percy et al. (2002) found that pest activity on aspen was altered by elevated levels of $\mathrm{CO}_{2}$ and $\mathrm{O}_{3}$.

\section{Pest threats}

All of the broadleaved species are host to a wide variety of native insects and diseases that affect their growth and mortality but the overall impact is thought to be relatively low (Klinka et al. 2000). Cottonwood is at high risk for butt and stem rots and most trees on upland sites are infected by age 20 (Simard and Vyse 1992). Bronze birch borer is the most seri-

${ }^{5} \mathrm{M}$. Cleary, forest pathologist, Southern Interior Region, BC Forest Service, Kamloops, BC. ous threat to birch in the southern Interior. Aspen faces moderate to high risk from butt and stem rots, stem cankers and leaf rust fungi (Lewis 1996). The most common diseases affecting aspen and other poplars in British Columbia were summarised by Callan (1998).

The threat of introduced pest organisms has not been fully evaluated for British Columbia. Callan (1998) warned of the threat to hybrid poplar plantations on the Coast from an introduced leaf rust. The poplar-willow borer (Cryptorhynchus lapathi L.) is associated with some loss of wood quality in cottonwood (Broberg et al. 2002), but its economic impact is unknown because there are no major markets for solid wood. Introductions of gypsy moth (Lymantria dispar L.) from either the east of North America, or from Asia, would have a major impact on all broadleaved species (Peterson et al. 1997). Plantation forestry using any of the major species might also exacerbate threats from both native and introducted organisms. Richardson et al. (2007) note that the poplar plantation program in Ontario was terminated because of a high incidence of disease.

\section{Current inventory data}

The most recent provincial inventory shows that there are 600 million cubic metres of broadleaved species in the Interior of the province (Fig. 1). This is 2.7 times the estimate provided by Massie et al. (1994), presumably because of new inventories and changes in merchantable limits. Aspen is the most prevalent species by volume and area, with more than twice the volume of the other 2 species groups combined. About $60 \%$ of the total volume is found in the Peace River and Fort Nelson regions east of the Rocky Mountains. West of the Rockies, there is a general decline in the amount of broadleaved species to the south and west. There is a relatively large volume of birch in the warm, moist valleys of the southern Interior. 


\section{Management of Broadleaved Species}

Past and present harvest levels

All of the major broadleaved species were widely used by First Nations peoples throughout the British Columbia Interior (Turner 1979). Birch bark was used to cover canoes and to create baskets for food storage. Birch wood was used for implements of many kinds and the sap was used as a drink. One First Nations leader has spoken of the " $\$ 1000$ birch tree" as a way of emphasizing the many traditional uses for a species (Royal Roads 2006). Large cottonwood trees were also used for dugout canoes for travelling the large lakes and rivers of the Interior. This species, like aspen, had numerous medicinal uses, in addition to serving as food and habitat for wildlife species harvested for the fur trade.

Since European settlement, commercial use of broadleaved species has been modest. For many years, cottonwood was the only species to be exploited on any scale to supply a paper mill in New Westminster. In the 1990s, there was a brief flurry of interest in aspen with investments in manufacturing plants to supply the Asian market with disposable chopsticks. This market faded quickly, but was replaced by one for OSB paneling in the north east of British Columbia using aspen and balsam poplar. Birch is also used for OSB but in small quantities.

In 2005-2006, the harvest of broadleaved species was 2.8 million cubic metres (BC MFR 2007a), and was concentrated in the Fort Nelson, Fort St. John and Dawson Creek Timber Supply Areas (TSA). In all 3 areas, the broadleaved species harvest of aspen and balsam poplar is managed under a partitioned cut, which means that Licensees have separate cuts for the species groups, and conifers cannot be substituted for broadleaves in the harvest operations. Birch is used as a raw material by a wide array of small-scale businesses (Royal Roads 2006) producing furniture, cabinetry, flooring, veneer, OSB, and firewood.

\section{Current commercial values}

Data on commercial values is limited because markets for broadleaved species are weak across the province. Market values for logs ranged between $\$ 30$ and $\$ 35$ per cubic metre between 2003 and 2007 (BCMFR 2008). Since current harvest and transportation costs range from $\$ 25$ to $\$ 35$, revenue to the Crown in the form of stumpage revenue rarely exceeds the legal minimum of $\$ 0.50$ per cubic metre. By comparison, stumpage prices for conifer species over the same time period ranged from $\$ 10$ to $\$ 35$ per cubic metre.

The mixed birch-conifer forests are the source of a lucrative, largely unregulated market for edible mushrooms in
Interior British Columbia. The commercial harvesting of wild edible mushrooms is a growing multi-million dollar industry in BCMF 1995).

\section{Potential for expansion in harvest of broadleaved species}

Optimistic forecasts for increased utilization of Interior broadleaved species have been made for 80 years (Peterson and Peterson 1996) and optimism still exists. Massie (1996) suggested that the potential level of harvest in British Columbia could reach 6.4 million cubic metres by 2016 . The principal opportunity is in the northeastern portion of the Province where the current level of broadleaf utilization is high, but below the established and potential AAC levels (see Table 1).

Some observers have suggested that global wood demand will lead to an increasing demand for British Columbia wood products and thus perhaps broadleaved species. A recent assessment by the US National Commission on Science for Sustainable Forestry (2005) is less optimistic. They point to a relatively flat demand for wood on a global basis and falling prices, and note that declining population growth in the developed world, greater efficiency of wood use, and expansion of forest plantations are contributing influences. Three factors could change this assessment with respect to broadleaves in British Columbia: the after-effects of the mountain pine beetle epidemic, the widespread use of carbon credit trading and the development of the biofuel industry.

Substantial reductions in timber supply over the next 10 to 15 years are expected as a result of the mountain pine beetle epidemic (BCMFR 2007c). Given that in some parts of the beetle-infested landscape, broadleaved species are the only green in a sea of red, their value is likely to rise. The most likely increase in utilization will be in the form of pulpwood as Interior mills seek to replace supplies of conifer chips.

The market in carbon credits could also have a substantial impact on the future use of broadleaves. Maturing stands of aspen, for example, have been shown to be among the largest carbon sinks in Canadian forests (FluxNet Canada 2004), pointing to opportunities for broadleaf forest conservation and afforestation. Trading in carbon credits and carbon offsetting is already underway in North America (Rudell et al. 2007). Credits based on afforestation could, for example, lead to investments in hybrid poplar plantations in the Peace River, where there is considerable potential on former agricultural crop lands (Kabzems 2006). Forest management credits might also be available for the increase in biomass in mixed broadleaved-conifer stands compared to the biomass produced under standard management practices (Man and Lieffers 1999, Valkonen and Valsta 2001).

Table 1. Current and potential annual allowable cut (AAC), and current broadleaf cut in the Peace River Region of British Columbia

\begin{tabular}{|c|c|c|c|c|c|}
\hline Timber Supply Area & $\begin{array}{l}\text { Current conifer and } \\
\text { broadleaf AAC } \\
\text { Million } \mathbf{m}^{3}\end{array}$ & $\begin{array}{l}\text { Broadleaf AAC } \\
\text { Million } \mathrm{m}^{3}\end{array}$ & $\begin{array}{c}\text { Current } \\
\text { broadleaf cut } \\
\%\end{array}$ & $\begin{array}{l}\text { Potential conifer } \\
\text { and broadleaf AAC } \\
\text { Million } \mathbf{m}^{3}\end{array}$ & $\begin{array}{c}\text { Potential } \\
\text { broadleaf AAC } \\
\text { Million } \mathbf{m}^{3}\end{array}$ \\
\hline Fort Nelson & 1.500 & 0.900 & 100 & 3.163 & 1.444 \\
\hline Fort St. John & 2.015 & 0.915 & 12 & 2.720 & 0.915 \\
\hline Dawson Creek & 1.733 & 0.886 & 42 & 2.078 & 0.880 \\
\hline
\end{tabular}

Sources: TSA Analysis Reports (BCMFR 2007b) 
Broadleaved species might also supply part of a developing market for biofuels. Biocap Canada (2008) has estimated that plantations of species such as aspen and willow represent about $1 / 4$ of the bioenergy potential from sustainable forestry. However, they warn that the cost is high relative to other forest-based opportunities and the economics of such operations may not currently be favourable in British Columbia.

\section{Current and future broadleaved management}

Management for broadleaved species is still at a very low level despite the publication of several management handbooks (Simard and Vyse 1992; Peterson and Peterson 1992, 1996; Peterson et al. 1997). The only widespread and deliberate management practices involve the natural regeneration of aspen following harvest of aspen-leading stands. Otherwise, the broadleaved species are tolerated at low levels and are generally targeted for removal in operations designed to achieve free-growing stands comprised of selected conifer species in the first few years following plantation establishment (Simard and Vyse 2006).

There is no commercial-scale planting of any of the native broadleaved species in the Interior. Only birch is produced in commercial nurseries, but on a small scale. Small hybrid poplar plantations have been established on private land in association with the City of Vernon to aid in land-based sewage effluent disposal (Carlson 1992). Some broadleaved species are used in road bank stabilisation and stream restoration activities.

There are 4 main impediments to the greater management of broadleaved species in the Interior. These are: (1) broadleaved volumes are dispersed in mixed species forests in the southern Interior; (2) solid wood quality is low because stands are old; (3) the tenure system is conifer-based and includes broadleaves only by default; and (4) the species selection and free-growing policies are too restrictive for broadleaved management.

Volumes of broadleaved species are spatially dispersed in mixed forests or along valley bottoms in the southern Interior of British Columbia, and there has been no interest in major investment to increase utilization. Current operations are small-scale and scattered. However, this situation could change in the future with maturity of second-growth stands in which broadleaves are managed in mixture with conifers. Unfortunately, conifer-centred stand management efforts in the 1990s reduced the future volume of broadleaves to low levels in many accessible areas (Simard et al. 2001) pushing back the time frame for future supplies.

Broadleaved species in southern British Columbia are usually harvested after their preferred rotation age, which is around 50 to 70 years (Simard and Vyse 1992), and hence the quality of harvested broadleaved stems is often low. They grow quickly but lose quality after 5 decades because of increased disease and declining stem form and solid wood quality.

Timber in British Columbia is harvested by private companies holding timber licenses granted under the Forest Act. The amount of timber harvested by a Licensee in any given TSA is subject to the AAC approved by the Chief Forester. Any timber cut by a Licensee is counted as part of its cut, regardless of value. Since no Licensee is interested in harvesting and selling low-value tree species when they can harvest higher-value conifers, there is a strong tendency to leave lowvalue species (such as broadleaves) in the forest. Small businesses report difficulties in obtaining a sufficient and regular supply of broadleaves (Royal Roads 2006) from major Licensees. Their main source of supply is from private timber and woodlots. Where separate allowable cuts for broadleaved species have been calculated, as for example in the Peace River country and in the Kamloops TSA, supply may improve.

Free-growing policies in several Canadian provinces have strongly encouraged removal of broadleaves from plantations to increase conifer production (Brand and Weetman 1986; Comeau et al. 2000; Wagner et al. 2001, 2005; Lieffers et al. 2002). These policies and practices are based on the assumptions that broadleaves compete intensively with conifers, they are of low importance to ecosystem function, their intensive removal will result in greater conifer productivity, and their economic value is low. While the policies have recently been relaxed in British Columbia to include some broadleaved trees as a component of acceptable stands, the effect on conifer crop tree growth must be minimal (BCMF 2000). This condition is rarely encountered because aspen, birch and cottonwood grow more rapidly in the first 10 to 20 years than most conifers. Thus, many conifer plantations in the Interior forests do not meet free-growing requirements without a brushing treatment to remove the broadleaved trees. Changes in this policy seem unlikely. Martin et al. (2005), in a report on species composition in regenerating cutblocks within TSAs affected by mountain pine beetle, recommend against any increase in broadleaved species composition above current low levels.

\section{Advantages of Managing For Broadleaves}

The ecological and economic value of broadleaved trees to forest ecosystems has received increasing attention in Europe and North America (Swanson et al. 1997, Lautenschlager 2000, Löfman and Kouki 2001, Comeau et al. 2005). The benefits of including some proportion of broadleaved species in future managed forests is widely recognised across western North America. Early reports concentrated on the value of broadleaves to wildlife (Enns et al. 1993) and the need to retain minor amounts of these species in future forests, particularly in riparian zones. With more research, the broader contribution of broadleaved species to biodiversity, forest health and ecosystem functioning has been increasingly recognized (Aitken et al. 2002, Lindenmayer and Franklin 2002, Simard et al. 2004, Hagar 2007) and the need for a multi-scale approach to planning species retention along multiple management pathways has been proposed (Comeau et al. 2005, Simard and Vyse 2006).

Broadleaves can have facilitative effects on conifer regeneration in mixed plantations, and their competitive effects vary over time and space, but the complexity of these interactions is ignored by free-growing policies. Even though birch and aspen can compete with conifers early in stand development, they self-thin, decline and die relatively quickly because they are pioneer species (Klinka et al. 2000, Comeau et al. 2003, Kabzems and Garcia 2004, Simard and Sachs 2004). Hence, their competitive effects on conifers are relatively short-lived over the rotation of a mixed stand (Frivold and Frank 2002, Simard et al. 2004). The beneficial effects of 
broadleaves in mixed stands include limiting spread of root disease among conifers (Morrison et al. 1988, Gerlach et al. 1997), reducing the risk of conifer attack by weevils and spruce budworm (Taylor et al. 1994, McIntosh et al. 1996), protecting understory conifers against frost (Andersson 1985, Pritchard and Comeau 2004), providing habitat for ungulates, small mammals and birds (Peterson et al. 1997, Aitken et al. 2002), and improving soil productivity through nutrient-rich litter inputs (Brockley and Sanborn 2003). In keeping with this last point, total yield (conifers plus broadleaves) in mixed forests has sometimes been higher than in pure coniferous forests because of niche complementarity (Kenk 1992, Mielikainen 1996, Frivold and Kolström 1999, Man and Lieffers 1999, Valkonen and Valsta 2001).

Extensive application of intensive conifer management that includes removal of broadleaves has raised concerns about the diversity, health and resiliency of the western North American forests (Lieffers et al. 2002). In addition to their lower structural diversity (Haeussler and Bergeron 2004), these conifer plantations have been subject to widespread insect and disease damage. In British Columbia, widespread damage from Dothistroma needle blight (Dothistroma septosporum [Dorog.] Morelet) (Woods et al. 2005) and Armillaria root disease (Armillaria ostoyae [Romag.] Herink) (Cruickshank et al. 1997) has been reported. More recently, the mountain pine beetle (Dendroctonous ponderosae Hopk.) has damaged thousands of hectares of young lodgepole pine plantations (Hawkins 2007). Pest damage, along with mortality caused by drought and fire, is expected to increase in British Columbia with climate change (Hamman and Wang 2006).

Concerns about environmental and economic costs of plantation-based forestry have led to more mixed conifer and broadleaved species management in Germany and Scandinavia (Kenk 1992, Puttonen 1996) and proposals for similar approaches in Western Canada (Lieffers et al. 1996, Comeau et al. 2005). Simard and Vyse (2006) have proposed a scheme for incorporating the many advantages of managing for broadleaves in British Columbia. They suggest 3 main pathways, to be applied in different proportions following harvesting across the landscape, arguing that the management program would be less costly in total, provide a greater range of forest products, provide a hedge against uncertainty in future wood product markets, and provide opportunities for the development of non-traditional forest products. They further suggest that a mixed conifer-broadleaved forest would provide a greater buffering capacity than single-species forests against the stresses that climate change will impose. Mixed forests serve as habitat for a rich array of plant and animal species and can provide connective corridors for northward migration of species with climate change (Paerson and Dawson 2005). Inclusion of broadleaves in critical patterns on the landscape for mitigating spread of wildfires has been studied for inclusion in landscape plans elsewhere in Canada (Parisien and Junor 2006).

\section{Scientific Background for Broadleaf Management General research conducted on broadleaves}

We evaluated the scientific background for future broadleaved species management and the existing information on gene conservation and tree improvement by survey- ing the scientific literature dealing with the 3 species of major importance in the Interior; we restricted our review to material published since the mid-1990s, when several broadleaved management handbooks were last published (Simard and Vyse 1992, Peterson and Peterson 1996, Peterson et al. 1997).

We identified 723 citations, most of which were published after 1993. Aspen was the subject of 60\%,20\% dealt with cottonwood, hybrid aspen and hybrid poplar, and 10\% focussed on birch. The relative neglect of birch is compensated to some degree by a large recent body of literature on 2 European birch species, (Betula pendula Roth and B. pubescens Ehrh), which share many features with paper birch. Balsam poplar was the least well studied. Studies ranged from a Populus monograph (Stettler et al. 1996) to very narrowly focussed papers dealing with the genetic structure of Populus species. There were relatively few product-oriented papers, but this may have been a function of the search methodology. A large number of investigations dealt with possible climate change effects on the broadleaved species. For example, there were numerous studies of physiological responses of aspen and other poplars to increased $\mathrm{CO}_{2}$ and $\mathrm{O}_{3}$ and some that measured carbon flux in regenerating stands of aspen. Few of the papers dealt with the effects of climate change on existing or potential damaging insects and diseases, or reported on measures that might support ecologically sound forestry to conserve native species mixtures. The citations are available in Vyse and Simard (2007).

\section{Silvicultural tests of broadleaf management}

The Experimental Project list available from the Provincial Forest Research Program ${ }^{6}$ shows that about 70 broadleaved species trials have been conducted since 1990. They range from studies examining nitrogen dynamics in conifer plantations to the effects of thinning in birch stands.

\section{Gene conservation and tree improvement programs}

Small programs for gene conservation of the major broadleaved species, except balsam poplar, have been started in British Columbia. In situ gene conservation has been evaluated for birch. Populations of birch have been reserved in parks and protected areas but some are under-represented (Centre for Forest Gene Conservation 2008). We suspect that this statement is also true for aspen, balsam poplar and cottonwood, based on their similar geographic distribution. $E x$ situ gene conservation is limited to birch and cottonwood.

A low level of broadleaved species genetic testing is also underway in the province. A small birch genecology program started in the mid-1990s and the first trial was established in 1996, testing 18 seed sources on 4 sites. A second trial was established in 1998, testing 195 wind-pollinated families, and a third, more elaborate genecology trial including selections from a provincial latitudinal and elevation grid was established in 2001. The family trial was the source of 36 clones for 2 paper birch seed orchards established in 2008 . Substantial productivity gains are expected as a result of the selection.

Trials of silver birch (Betula pendula) using seed from the Finnish breeding program have been grown at Skimikin

$\overline{{ }^{6} \text { File provided by K. Soneff, Forest Science Manager, Southern }}$ Interior Region, BC Ministry of Forests and Range. 
Nursery near Salmon Arm B.C. for nearly 20 years. These trees have reached $20 \mathrm{~m}$ in height after 15 years, but are slender, with diameters of $15 \mathrm{~cm}$ to $20 \mathrm{~cm}$ and they are now suffering from birch decline. Silver birch has not been used in plantation trials.

Material from about 50 aspen sources was collected for a genecology trial in the mid-1990s (BCMFR 2007d), but the field trials have not been implemented. Hybrid aspen ( $\mathrm{Popu-}$ lus tremula $\times$ tremuloides) material from the Lake States of the US has been established on 3 sites in the Interior.

Genecological work on the Populus subpecies began in 2004, when material from around British Columbia was planted in test sites at Harrison Lake, Prince George and Terrace. Studies testing Populus hybrids began much earlier, in 1984, at Kalamalka Research Station (Vernon, British Columbia), using material supplied initially by the poplar breeding program at the University of Washington. Field tests of large numbers of hybrid clones were initiated in 1988 (Carlson 1996), with out-plantings at numerous locations in the Interior. Good growth occurred, but only under intensive cultivation conditions, including irrigation with wastewater (Carlson 1992). Recent work has involved testing 50 clones of hybrids between cottonwood from central British Columbia and eastern cottonwood (P. deltoides) from northern origins.

Although the genetic programs for broadleaved species are small in the province, this is partly offset by efforts in the Prairie Provinces. The Western Boreal Aspen Corporation has initiated trials of plantation silviculture and aspen provenances, and has started a tree improvement program with native aspen and balsam poplar as well as hybrid aspen and poplar (Alberta Forest Genetics Resources Council 2005).

\section{Recommendations for future genetic research}

We recommend only modest expansion of the genetic improvement research for broadleaved species of Interior British Columbia at this time on the grounds that there will be few opportunities for deployment of improved broadleaved varieties in the near future. While the slow expansion of broadleaved species utilization is likely to continue, we also expect that management intensity will remain low. In the south, mixed species management is expanding and could accelerate rapidly if free-growing policy constraints are removed. However, the renewal of broadleaved species throughout the Interior is based on natural regeneration, and opportunities for using improved stock in renewal programs are limited. Small "niche" opportunities may emerge, such as the creation of biofuel plantations on agricultural land in the Peace River region, or the use of paper birch in conifer mixtures for treatment of root-diseased areas in the southern Interior. However, we caution that some of the assumptions and assertions we have made in our assessment may not hold if the current economic crisis in the forest industry, changes in energy policies, and uncertainty about climate change effects on forest ecosystems lead to dramatic changes in forest policy and management. Thus, we suggest that the question of further expansion of effort should be revisited within 5 years.

We strongly advocate expansion of the existing work on the genecology of broadleaved species. Given the uncertain future, we expect that the modest investment required to protect gene resources and to gain a greater understanding of our ecologi- cally important but neglected broadleaved species will prove wise. Indeed, this improved protection and understanding will be critical if governments undertake programs to facilitate tree species migration to cope with climate change, whether it involves active movement of species or simply conservation of species corridors for natural migration.

In summary, we suggest the following specific actions are warranted in light of our findings:

1. Continue genecological investigations of birch and cottonwood;

2. Initiate genecological investigations in aspen and balsam poplar;

3. Implement a systematic gene conservation program for all Interior British Columbia broadleaved species;

4. Initiate studies of the use of fast-growing varieties and hybrids of aspen, cottonwood, balsam poplar and native willows on cleared land for bioenergy and carbon capture crops in the Peace River region, in cooperation with the Alberta Forest Genetics Resources Council.

5. Continue the current moderate level of genetic improvement work in birch, with the aim of establishing a network of trial plantations of birch and mixtures of birch and improved conifer material, on suitable sites in the Interior;

6. Establish "smart mixture" trials (Aitken et al. 2008) where a range of genetically improved mixtures of conifers and broadleaves is tested on an operational scale across a latitudinal gradient for future facilitated migration programs with climate change;

7. Maintain cottonwood and silver birch genetic improvement work at current low levels;

8. Investigate the potential of using improved birch in conjunction with Armillaria management efforts in the southern Interior;

9. Investigate the role of native and exotic insect and disease pests as well as climatic and site factors on the existing and potential decline of broadleaves with climate change;

10. Strengthen existing cooperation among genetics specialists in research programs and tree physiologists, ecologists, silviculturalists and forest insect and disease specialists with the aim of establishing a strong scientific basis for management of broadleaved species in pure and mixed stands.

\section{Acknowledgements}

This paper is a distillation of a broader report written for the Forest Genetics Council of British Columbia in 2007 (Vyse and Simard 2007). We thank the Council for the opportunity to carry out this research. Much has already been written about the occurrence of broadleaved tree species in British Columbia and this material has provided an excellent base for our study. We are also indebted to our colleagues for their willingness to share their views on the management of broadleaved species so freely. We thank Jean Roach for her contributions to the literature review.

\section{References}

Aitken, K.E.H., K.L. Wiebe and K. Martin. 2002. Nest-site re-use patterns for a cavity-nesting bird community in interior British Columbia. The Auk 119: 391-402. 
Aitken, S.N., S. Yeaman, J.A. Holliday, T. Wang and S. CurtisMcLane. 2008. Adaptation, migration or extirpation: Climate change outcomes for tree populations. Evolutionary Applications. 1: 95-111. Alberta Forest Genetics Resources Council. 2005. Annual Report 2004-2005. Edmonton, AB. Available at http://www.abtreegene. com/ [Accessed Feb 2008].

Andersson, S. 1985. Treatment of young mixed stands with birch and conifers. In B. Hagglund and G. Peterson (eds.). Broadleaves in boreal silviculture - an obstacle or an asset? pp. 127-162. Swedish Univ. Agr. Sci. Dept. Silv. Umeå, Sweden.

Biocap Canada. 2008. An information guide on pursuing biomass energy opportunities and technologies in British Columbia for First Nations, small communities, municipalities and industry. BC Ministry of Energy, Mines and Petroleum Resources, BC Ministry of Forests and Range, Victoria, BC. 80 p.

Bourque, C.P.-A., R.M. Cox, D.J. Allen, P.A. Arp and F.-R. Meng. 2005. Spatial extent of winter thaw events in eastern North America: historical weather records in relation to yellow birch decline. Global Change Biology 11: 1477-1492.

Brand, D.G. and G.F. Weetman. 1986. Standards for Regeneration Establishment in Canada: A Case Study for Douglas-fir. For. Chron. 62: 84-90.

[BCMF] British Columbia Ministry of Forests. 1995. Botanical Forest Products in British Columbia - An Overview. For. Prac. Br., BC Ministry of Forests, Victoria, BC.

2000. Establishment to free growing guidebook. Kamloops Forest Region. Rev. ed. Version 2.2. Ministry of Forests, Forest Practices Code of British Columbia Guidebook. Victoria, BC.

[BCMFR] British Columbia Ministry of Forests and Range 2006. State of the B.C.s Forests 2006. Victoria, BC. 182 p. Available at http://www.for.gov.bc.ca/hfp/sof/\#2006_Report. [Accessed_July 2008].

2007a. Annual Report for 2005-06. Available at http://www.for.gov.bc.ca/mof/annualreports.htm [Accessed July 2008].

2007b. Timber supply analysis reports for Fort Nelson, Fort St. John and Dawson Creek. Available at http://www.for.gov.bc.ca/ hts/tsas.htm [Accessed July 2008].

2007c. Timber Supply and the Mountain Pine Beetle Infestation in British Columbia - 2007 Update Forest Analysis Branch, Victoria, B.C. Available at http://www.for.gov.bc.ca/hfp/mountain pine_beetle/Pine_Beetle_Update20070917.pdf [Accessed July 2008].

2007d. Tree Improvement Branch Seed Planning Unit \#48

Commercial Broadleaves - Interior. Available at http://www.for.gov. bc.ca/hti/speciesplan/index.htm [Accessed July 2008].

. 2008. Interior Log market 3 month summaries. Available at http:// www.for.gov.bc.ca/hva/logreports_interior.htm [Accessed July 2008]. Broberg C.L., J.H. Borden and L.M. Humble. 2002. Distribution and abundance of Cryptorhynchus lapathi on Salix spp. in British Columbia. Can J. For Res. 32: 561-568.

Brockley, R.P. and P. Sanborn. 2003. Effects of Sitka alder on the growth and foliar nutrition of young lodgepole pine in the central interior of British Columbia. Can. J. For. Res. 33: 1761-1771.

Callan, B.E. 1998. Diseases of Populus in British Columbia: a diagnostic manual. Nat. Resour, Can., Can. For. Serv., Victoria, BC. 157 p. Carlson, M.R. 1992. Municipal effluent irrigation of fast-growing hybrid poplar plantations near Vernon, British Columbia. For. Chron. 68: 206-208.

Carlson, M.R. 1996. Evaluation and testing of hybrid poplars in British Columbia. In P.G. Comeau et al. (eds.). Ecology and management of B.C. Hardwoods. pp. 113-114. FRDA Rep. No. 255. BC Ministry of Forests, Victoria, BC.

Carlson. M.R., V. Berger and C.D.B. Hawkins. 2000. Seed source testing of paper birch in British Columbia. J. Sustain. For. 10:25-34. Centre for Forest Gene Conservation. 2008. Cataloguing In situ genetic resources. University of British Columbia. Available at http://www.genetics.forestry.ubc.ca/cfcg/proj_cataloguing/in_situ_ main.html [Accessed Feb 2008].
Comeau, P.G., B.S. Biring, and G.J. Harper. 2000. Conifer responses to brushing treatments: a summary of British Columbia data. BC Ministry of Forests Extension Note 41. Victoria, BC.

Comeau, P.G., G. J. Harper, M.E. Blache, J.O. Boateng and K.D. Thomas. (eds). 1996. Ecology and management of B.C. Hardwoods. BC Ministry of Forests. FRDA Rep. No. 255. Victoria, BC.

Comeau, P.G., R. Kabzems, J. McClarnon and J.L. Heineman. 2005. Implications of selected approaches for regenerating and managing western boreal mixedwood. For. Chron. 81:559-574.

Comeau, P.G., J.R. Wang and T. Letchford. 2003. Influences of paper birch competition on growth of understory white spruce and subalpine fir following spacing. Can. J. For. Res. 33: 1962-1973.

Cruickshank, M.G., D.J. Morrison and Z.K. Punja. 1997. Incidence of Armillaria species in precommercial thinning stumps and spread of Armillaria ostoyae to adjacent Douglas-fir trees. Can. J. For. Res. 27: 481-490.

Enns, K.A., E.B. Peterson and D. McLennan. 1993. Impacts of hardwood management on British Columbia wildlife: problem analysis. For. Can and Ministry of Forests. FRDA Report 208.

Fluxnet-Canada. 2004. Annual progress report. Fluxnet-Canada Network Management Office, Faculté de Foresterie et de Géomatique, Université Laval, Québec, QC. 210 p.

Frivold, L.H. and J. Frank. 2002. Growth of mixed birch-coniferous stands in relation to pure coniferous stands at similar sites in southeastern Norway. Scand. J. For. Res. 17: 139-149.

Frivold, L.H. and T. Kolström. 1999. Yield and treatment of mixed stands of boreal tree species in Fennoscandia. In A.F. Olsthoorn, F.M. Bartelink, J.J. Gardiner, H. Pretzsch, H.J. Hekhuis, and A. Franc (eds.). Management of Mixed-species Forest: Silviculture and Economics. pp. 37-45. IBN-DLO, Wageningen.

Gerlach, J.P., P.B. Reich, K. Puettmann and T. Baker. 1997. Species, diversity, and density affect tree seedling mortality from Armillaria root rot. Can. J. For. Res. 27: 1509-1512.

Haeussler S. and Y. Bergeron. 2004. Range of variability in boreal aspen plant communities after wildfire and clear-cutting. Can. J. For. Res. 34: 274-288.

Hagar, J.C. 2007. Wildlife species associated with non-coniferous vegetation in Pacific Northwest conifer forests: A review. For. Ecol. Manage. 246: 108-122.

Hamann, A. and T. Wang. 2006. Effects of climate and climate change on ecosystem and tree species distribution in British Columbia. Ecology 87: 2773-2786.

Hawkins, C. 2007. Mountain Pine Beetle Impacts on Young Age Class Pine Leading Stands in the SBS Biogeoclimatic Zone Executive Summary FIA-FSP Project: M08-6024. Available at http://www. for.gov.bc.ca/hfd/library/FIA/2008/FSP_M086024.pdf [Accessed July 2008]

Hogg, E.H., J.P. Brandt and B. Kochtubajda. 2002. Growth and dieback of aspen forests in northwestern Alberta, Canada, in relation to climate and insects. Can. J. For. Res. 32: 823-832.

Kabzems, R. 2006. Hybrid Poplar Potential in the Peace Forest District. BC Ministry of Forests and Range, Northern Interior Region. Internal report. $5 \mathrm{p}$.

Kabzems, R. and O. Garcia. 2004. Structure and dynamics of trembling aspen - white spruce mixed stands near Fort Nelson, B.C. Can. J. For. Res. 34: 384-395.

Kenk, G.K. 1992. Silviculture of mixed species stands in Germany. In M.G.R. Cannell, D.C. Malcom and P.A. Robertson (eds.). The ecology of mixed species stands of trees. Blackwell Scientific Publ. Br. Ecol. Soc. 11: 53-63.

Klinka, K, J. Worrall, L. Skoda and P. Varga. 2000. The distribution and synopsis of ecological and silvical characteristics of tree species of British Columbia's forests. Canadian Cartographics Ltd., Vancouver, BC. 180 p.

Lautenschlager, R.A. 2000. Can intensive silviculture contribute to sustainable forest management in northern ecosystems? For. Chron. 76: 283-295. 
Lewis, K.J. 1996. Aspen decay and wood utilization. In P.G. Comeau et al. (eds.). Ecology and management of B.C. Hardwoods. pp. 65-74. FRDA Rep. No. 255. BC Ministry of Forests, Victoria, BC.

Lieffers, V.J., R.B. Macmillan, D. MacPherson, K. Branter and J.D. Stewart 1996. Semi-natural and intensive silvicultural systems for the boreal mixedwood forest. For. Chron. 72: 286-292.

Lieffers, V.J., B.D. Pinno and K.J. Stadt. 2002. Light dynamics and free-to-grow standards in aspen-dominated mixedwood forests. For. Chron. 78: 137-145.

Lindenmayer, D.B and J.F.Franklin. 2002. Conserving forest biodiversity: a comprehensive multi-scaled approach. Island Press, Washington, DC.

Löfman, S. and J. Kouki. 2001. Fifty years of landscape transformation in managed forests of southern Finland. Scand. J. For. Res. 16: 44-53.

Man, R. and V.J. Lieffers. 1999. Are mixtures of aspen and white spruce more productive than single species stands? For. Chron. 75: 505-513.

Martin, P., B. Barber, C. Delong, D. Meidinger and M. Pelchat. 2005. Management of Species Composition in Cutblocks in Beetleimpacted TSAs. Ministry of Forests and Range, Forest Practices Branch. 120 p. Available at http://www.for.gov.bc.ca/hfp/mountain_pine_beetle/SpeciesManagement.pdf [Accessed July 2008].

Massie M.R.C. 1996. Hardwood utilization and supply. In P.G. Comeau et al. [eds.]. Ecology and management of B.C. Hardwoods. pp. 1-7. FRDA Rep. No. 255. BC Ministry of Forests, Victoria, BC.

Massie, M.R.C., E.B. Peterson, N.M.Peterson and K.A. Enns. 1994. An assessment of the strategic importance of the hardwood resource in British Columbia. FRDA Report 221. BC Ministry of Forests and Forestry Canada, Victoria, BC. 206 p.

McIntosh, R.L., J.A. McLean, R.I. Alfaro and G.K. Kiss. 1996. Dispersal of Pissodes strobi in putatively resistant white spruce in B.C. For. Chron. 72: 381-387.

McKenney, D.W., J.H.Pedlar, K. Lawrence, K. Campbell and M. F. Hutchinson. 2007. Potential impacts of climate change on the distribution of North American trees. Bioscience. 57: 939-948.

Mielikainen, K. 1996. Approaches to managing birch dominated mixed stands in Finland. In P.G. Comeau and K.D. Thomas (eds.). Silviculture of Temperate and Boreal Broadleaved-Conifer Species: Proceedings of a Workshop held Feb. 28-March 1, 1995, Richmond, BC. Land Manage. Handb. 36. pp. 122-125. BC Ministry of Forests, Victoria, BC.

Morrison, D.J., G.W. Wallis and L.C.Weir. 1988. Control of Armillaria and Phellinus root diseases: 20 year results from the Skimikin stump removal experiment. Can. For. Serv. Pac. For. Centre, Victoria, BC. Info. Rept. BC-X-302.

Paerson R.G. and T.P. Dawson. 2005. Long distance plant dispersal and habitat fragmentation: identifying conservation targets for spatial landscape planning under climate change. Biological Conservation 123: 389-401.

Parisien M-A. and D. Junor 2006. The relationship between burn probability and fuel type dominance in the boreal mixedwood of western Canada. Prince Albert Model Forest Short report. Available at http://www.pamodelforest.sk.ca/pubs/PAMF_short_report March_2006.pdf [Accessed July 2008].

Percy, K.E., C.S. Awmack, R.L. Lindroth, M.E. Kubiske, B.J. Kopper, J.G. Isebrands, K.S. Pregitzer, G.R. Hendrey, R.E. Dickson, D.R.Zak, I. Oksanen, J. Dober, R. Harrington and D.F. Karnosky. 2002. Altered performance of forest pests under $\mathrm{CO}_{2}$ and $\mathrm{O}_{3}$ enriched atmospheres. Nature 420: 403-407.

Peterson. E. B. and N. M. Peterson 1992. Ecology management and use of aspen and balsam poplar in the Prairie Provinces. Canadian Forest Service, Northern Forestry Station, Special report \#1. Edmonton, $\mathrm{AB}$.

Peterson, E. B and N. M. Peterson. 1996. Ecology and silviculture of trembling aspen. In P.G. Comeau, G.J. Harper, M.E. Blache, J.O. Boateng and K.D. Thomas (eds.). Ecology and management of B.C. Hardwoods. FRDA Report \# 255. BC Ministry of Forests, Victoria, BC.
Peterson, E.B., N.M. Peterson, S.W. Simard and J.R.Wang. 1997. Paper birch managers' handbook for British Columbia. FRDA Rep. 271. Forestry Canada and BC Ministry of Forests, Victoria, BC.

Pritchard, J.M. and P.G. Comeau. 2004. Effects of opening size and stand characteristics on light transmittance and temperature under young trembling aspen stands. For. Ecol. Manage. 200: 119-128.

Puttonen, P. 1996. Birch management in Finland. In P.G. Comeau, G.J. Harper, M.E. Blache, J.O. Boateng and K.D. Thomas (eds.). Ecology and management of B.C. Hardwoods. FRDA Report \# 255. pp. 177-187. BC Ministry of Forests, Victoria, BC.

Richardson, J., J.E.K. Cooke, J.G. Isebrands, B.R. Thomas and K.C.J. Rees. 2007. Poplar research in Canada - a historical perspective with a view to the future. Can J. Bot. 85: 1136-1146.

Royal Roads. 2006. Market and Product Development for Birch Timber and Non-Timber Products: Current Status and Potential in British Columbia. Royal Roads University, The Centre for Non-Timber Resources, Victoria, BC. Report prepared for Forest Innovation

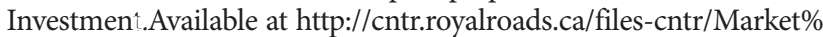
20and\%20Product\%20Development $\% 20$ for\%20Birch\%20Timber. pdf [Accessed July 2008].

Rudell, S., R. Sampson, M.Smith, R. Giffen, J. Cathcart, J. Hagan, D. Sosland, J, Godbee, J. Heisenbuttle, S.Lovett, J. Helms, W. Price and R. Simpson. 2007. The role for sustainably managed forests in climate change mitigation. J. For. 105: 314-319.

Simard, S.W., J.L. Heineman, W.J. Mather, D.L. Sachs and A. Vyse. 2001. Effects of operational brushing on conifers and plant communities in the southern interior of British Columbia: results from PROBE 1991-2000 PRotocol for operational brushing evaluations. Research Branch, BC Ministry of Forests, Land Manage. Handb. No. 48. Victoria, BC.

Simard, S.W. and D.L.Sachs. 2004. Assessment of interspecific competition using relative height and distance indices in an age sequence of seral interior cedar-hemlock forest in British Columbia. Can. J. For. Res. 34: 1228-1240.

Simard, S.W., D.L. Sachs, A. Vyse, and L.L. Blevins. 2004. Paper birch competitive effects vary with conifer tree species and stand age in interior British Columbia forests: implications for reforestation policy and practice. For. Ecol. Manage. 198: 55-74.

Simard, S.W. and A. Vyse. 1992. Ecology and management of paper birch and black cottonwood in southern British Columbia. Land Management Report 75. BC Ministry of Forests Research Program, Victoria, BC. 62 p.

Simard, S. and A. Vyse. 2006. Trade-offs between competition and facilitation: a case study of vegetation management in the interior cedar-hemlock forests of southern British Columbia. Can. J. For. Res. 36: 2486-2496.

Stettler, R.F., H.D. Bradshaw Jr., P.E. Heilman and T.M. Hinckley. (eds). 1996. Biology of Populus and its implications for management and conservation. NRC Research Press, Ottawa, ON.

Swanson, F.J., J.A. Jones and G.E. Grant. 1997. The physical environment as a basis for managing ecosystems. In K.A. Kohm and J.F. Franklin (eds.). Creating a forestry for the $21^{\text {st }}$ century: the science of ecosystem management. pp. 229-238. Island Press, Washington, DC. Taylor, S.P., R.I. Alfaro, C. DeLong, and L. Rankin. 1994. Effects of overstory shading on white pine weevil damage to interior white spruce. In: R.I. Alfaro, G. Kiss, and R.G. Fraser (eds.). The white pine weevil: biology, damage and management. Proc. Symp., January 19-21, 1994, Richmond, BC. pp. 254-261. FRDA Report 226. Forestry Canada., Victoria, BC.

Turner, N. J. 1979. Plants in British Columbia Indian technology. B.C. Provincial Museum Handbook no. 38. BC Provincial Museum, Victoria, BC. $304 \mathrm{p}$

U.S. National Commission on Science for Sustainable Forestry. 2005. Global markets forum. Summary report of the National Commission on Science for Sustainable Forestry. NCSSF Project C9. Washington, DC. 20 p.

Valkonen, S. and L. Valsta. 2001. Productivity and economics of 
mixed two-storied spruce and birch stands in Southern Finland simulated with empirical models. For. Ecol. Manage. 140: 133-149.

Vyse, A. and S.W. Simard. 2007. Broadleaved species status report for the British Columbia Interior. Forest Genetics Council of British Columbia. 102p. Available at http://www.fgcouncil.bc.ca/doc.html [Accessed July 2008].

Wagner, R.G., F.W. Bell and R.A. Campbell. 2001. Vegetation management. In R.G. Wagner and S.J. Colombo (eds.). Regenerating the Canadian Forests: Principles and Practice for Ontario. pp. 431-457. Fitzhenry and Whiteside, Markham, ON.
Wagner, R.G., K.M. Little, B. Richardson and K. McNabb. 2005. The role of vegetation management for enhancing productivity of the world's forests. Forestry 79: 57-79.

Worrall, J.J, L. Egeland, T. Eager, R. A. Mask, E. W. Johnson, P. A. Kemp and W. D. Shepperd. 2008. Rapid mortality of Populus tremuloides in southwestern Colorado, USA. Forest Ecology and Management. 255(3-4): 686-696.

Woods, A.J., K.D. Coates and A. Hamann. 2005. Is an unprecedented Dothistroma needle blight epidemic related to climate change? Bioscience 55: 761-769. 